Journal of Food Technology 9 (1): 27-31, 2011

ISSN: $1684-8462$

(C) Medwell Journals, 2011

\title{
Selected Quality Attributes of Jam Produced from Osmo-Dehydrated Cashew Apple
}

\author{
${ }^{1}$ S.A. Oyeyinka, ${ }^{1}$ B.I.O. Ade-Omowaye, ${ }^{1}$ P.O. Ngoddy and ${ }^{2}$ O.R. Karim \\ ${ }^{1}$ Department of Food Science and Engineering, Lautech, \\ P.M.B. 4000 Ogbomoso, Oyo State, Nigeria \\ ${ }^{2}$ Department of Home Economics and Food Science, University of Ilorin, \\ P.M.B. 1515 Ilorin, Kwara State, Nigeria
}

\begin{abstract}
Osmotic Dehydration (OD) with sugar solutions has been described as a suitable method for preserving fruit quality to a great extent. In this study, pre-frozen whole cashew apples were soaked in varying osmotic solution concentrations $\left(50^{\circ}, 60^{\circ}\right.$ and $70^{\circ}$ Brix) at different soaking times $(3,4$ and $5 \mathrm{~h}$ ) before conversion into jam. Jam made with sugar solution of $60^{\circ}$ Brix without osmotic treatment served as the control sample. The jam samples were analyzed for $\mathrm{pH}$, total soluble solids ( ${ }^{\circ} \mathrm{Brix}$ ), Titratable Acidity (TTA), ascorbic acid content and Moisture Content (M.C). Sensory attributes of the samples were also evaluated. It was observed that as soaking time progressed, TTA, M.C and vitamin C decreased gradually while the $\mathrm{pH}$ value increased. Increase in osmotic solution concentration resulted in reduced TTA, M.C and vitamin C with corresponding increase in $\mathrm{pH}$ and Brix values. Generally, jam made from $50^{\circ}$ Brix for 3 and $4 \mathrm{~h}$ were most preferred by the panelists. However, the observation of the panelists reveals that soaking in $50^{\circ}$ brix for $3 \mathrm{~h}$ yielded jam products with better sensory attributes. The result from this study has demonstrated the potential of cashew apple in jam making and has provided useful product development outlets for osmotic solutions which until now have remained grossly underutilized in Nigeria and other countries.
\end{abstract}

Key words: Cashew apple, osmotic-dehydration, jam, quality characteristics, sensory attributes, Nigeria

\section{INTRODUCTION}

Nigeria has been reported to be one of the main producers of cashew. Cashew is an important cash crop grown in Nigeria yielding about 660,000 tons of raw nuts in 2007. The annual production of cashew apple in Nigeria is about 5.2 million tonnes, most of which deteriorates because of inadequate storage facilities (Cormier, 2008).

It has been revealed that only about $10 \%$ of cashew production in Nigeria is consumed either in raw or processed form (Oduwole et al., 2001). Cashew apple is a valuable source of minerals and vitamins. Indeed, cashew apple is reported to contain 5 times as much vitamin $\mathrm{C}$ as citrus juice (Akinwale, 2000) and 10 times as pineapple (Ohler, 1988). The cashew apple juice also has medicinal uses. For instance, its high tannin content makes it a suitable remedy for sore throat and chronic dysentery in Cuba and Brazil (Morton, 1987). It was also reported to have anti-bacterial, anti-oxidant (Melo-Cavalcante et al., 2003) and anti-mutagenic properties (Cavalcante et al., 2005). Industrial application of cashew apple is limited in Nigeria however, few reports have demonstrated possible products from the apple including wine (Aderiye et al., 1991; Akinwale, 1999; Shuklajasha et al., 2006) jam and preserves (Ogunmoyela, 1983); conversion of apple juice into alcohol and non-alcoholic beverages, candied fruit, fresh juice, jelly, syrup and pectin (Winterhalter, 1991) and sun-dried cashew apple (Morton, 1987).

Jams are products formulated from a minimum fruit content of $40 \%$ and a final soluble solid content of $45^{\circ}$ Brix. Some additives such as citric acid, gelling agents and pectin can be added (Garcia-Martinez et al., 2002). In conventional jam manufacture, all the ingredients are mixed in predetermined proportions and the mix is concentrated by applying thermal treatments at normal or reduced pressure to reach the final soluble solid content. This process leads to thick consistency, destroys fruit enzymes, extracts some of the pectin from the fruit and concentrates the product to a point where as a result of its acidity and reduced water activity becomes self-preserving (Garcia-Martinez et al., 2002). This process induces undesirable changes in colour, texture, nutritive value and flavour due to prolonged cooking process. In response to the challenges posed by severe temperature processing, milder processes such as

Corresponding Author: S.A. Oyeyinka, Department of Food Science and Engineering, Lautech, P.M.B. 4000 Ogbomoso, Oyo State, Nigeria 
Osmotic dehydration, high pressure processing and pulsed electric fields, either singly or in combination as in hurdle technology have been suggested for preserving fruits and vegetables (Ade-Omowaye et al., 2007).

Osmotic Dehydration (OD) is a technique used for concentrating fruits and vegetables by placing them in aqueous solutions with high osmotic pressure such as sugar syrup or brine. It results in products with good flavour, aroma, nutritional content and small mineral and vitamin losses (Ade-Omowaye et al., 2007). In addition, the osmotic solution used for fruit dehydration can be adequately formulated with additives and added to fruit in order to produce jams (Garcia-Martinez et al., 2002).

Through this method, solutes possibly lost during the OD process can be recovered. This study therefore aimed at producing and evaluating an acceptable jam from cashew apple using osmotic dehydration as a pre-processing step.

\section{MATERIALS AND METHODS}

Fresh cashew apple was obtained from an agricultural farm in Ogbomoso while food grade commercial sucrose, gelling agent (pectin) and acidity agent (citric acid) were purchased from a laboratory chemical store in Lagos state, Nigeria.

Osmotic treatment: Pre-frozen cashew samples were thawed by dipping in cold water and blotted with tissue paper to remove external moisture before subjecting to osmotic dehydration in the prepared osmotic solutions $\left(50^{\circ}, 60^{\circ}\right.$ and $70^{\circ}$ Brix). The temperature of the osmotic solutions was maintained at $35 \pm 5^{\circ} \mathrm{C}$ in a thermostatically controlled water bath. The ratio of fruit pieces to that of the medium was maintained at 1:10 in order to ensure that the concentration of the osmotic solution did not change significantly during the experiment. Samples were withdrawn at $3-5 \mathrm{~h}$ before further processing into jam.

Jam preparation: Operating conditions were determined from preliminary studies. The osmotically pre-treated fruit samples were crushed in a Warring commercial blender (Model number: 35BL64, Serial number: 001843A, USA) until a uniform mixture was formed.

Equal volumes of the osmotic solution and the crushed cashew apple were used in the formulation. Acidifying ( $0.4 \%$ citric acid) and gelling $(0.4 \%$ pectin) agents were added to the osmotic solution, heated to about $80^{\circ} \mathrm{C}$ for complete dissolution, before the addition of the crushed cashew apple (Garcia-Martinez et al., 2002). The resultant mixture was heated at $80^{\circ} \mathrm{C}$ until it sets. The jams were hot-filled into sterilized jars, sealed and rapidly cooled under running water to minimize thermal stress. The products were stored under refrigeration until further analysis.

Quality evaluations: Titratable Acidity (TTA), $\mathrm{pH}$, moisture content, total soluble solids (Brix) and vitamin C contents were determined using methods described by AOAC (1990).

Sensory evaluation: The jam samples along with bread serving as a carrier were presented to 10 semi-trained panelists using the method described by Taiwo et al. (1997). The panelists were asked to indicate their observations using a 9 point hedonic scale for aroma, colour, taste and overall acceptability. Like extremely and dislike extremely were ranked 9 and 1, respectively. Descriptive terms that were converted to numerical scores were however adopted to assess the products texture (Firm: 3, Fairly Firm: 2, Less Firm: 1) after taste (Astringent: 1, Slightly astringent: 2, Not astringent: 3 and spreadability (Very good: 3 , Good: 2, Poor: 1 ).

Statistical analysis: All analyses were carried out in triplicates. Data were subjected to Analysis of Variance (ANOVA) and means were separated using Duncan's Multiple Range Test at $\mathrm{p} \leq 0.05$ (Steel and Torrie, 1980; Gomez and Gomez, 1985).

\section{RESULTS AND DISCUSSION}

The chemical compositions of the jam samples made from cashew apples soaked in $50^{\circ}$ brix soaked for varying periods of 3-5 h are shown in Table 1 . The observed TTA values decreased significantly $(p \leq 0.05)$ up to the 4 th $h$ of soaking after which the reduction became insignificant. However, jam produced from cashew soaked for $3 \mathrm{~h}$ did not differ significantly from the control sample.

In addition, soaking beyond $3 \mathrm{~h}$ resulted in jam samples with TTA values that were significantly different from the control samples. A corresponding increase in the $\mathrm{pH}$ values (3.57-3.72) was noted in the jam samples as soaking time progressed. The trend of increase was similar to the decreasing trend recorded for the TTA values of jam samples produced from cashew apple soaked in $50^{\circ}$ brix at varying soaking time (Table 1).

This observation indicates that soaking beyond $3 \mathrm{~h}$ did not yield jam products significantly different from each other in terms of TTA and pH suggesting an optimal soaking time for jam preparation. Similarly, increase in osmotic solution concentration $\left(50^{\circ}, 60^{\circ}\right.$ and $70^{\circ}$ Brix), (Table 2) resulted in reduced TTA (0.070-0.113) with corresponding increase in $\mathrm{pH}$ values (3.59-3.76). 
Table 1: Effect of immersion time on the chemical composition of Jam produced from cashew apple soaked in $50^{\circ}$ brix osmotic solution

\begin{tabular}{lcccccc}
\hline Samples & TI $(\mathrm{h})$ & TTA $(\%)$ & $\mathrm{pH}$ & Brix $\left(^{\circ}\right)$ & M.C $(\%)$ & Vit C (mg/100 $)$ \\
\hline A & 0 & $0.123 \pm 0.01^{\mathrm{a}}$ & $3.57 \pm 0.01^{\mathrm{c}}$ & $58 \pm 0.00^{b}$ & $68.19 \pm 0.590$ & $105.26 \pm 0.00^{\mathrm{a}}$ \\
B & 3 & $0.113 \pm 0.01^{\mathrm{a}}$ & $3.59 \pm 0.01^{\mathrm{c}}$ & $44 \pm 0.00^{\mathrm{e}}$ & $78.23 \pm 1.320^{\mathrm{a}}$ & $82.72 \pm 0.01^{\mathrm{b}}$ \\
$\mathrm{C}$ & 4 & $0.090 \pm 0.00^{b}$ & $3.71 \pm 0.01^{\mathrm{a}}$ & $48 \pm 0.00^{\mathrm{d}}$ & $76.96 \pm 0.540^{\mathrm{b}}$ & $75.68 \pm 0.01^{\mathrm{c}}$ \\
$\mathrm{D}$ & 5 & $0.089 \pm 0.00^{\mathrm{b}}$ & $3.72 \pm 0.01^{\mathrm{a}}$ & $48 \pm 0.00^{\mathrm{d}}$ & $75.55 \pm 0.350^{\mathrm{b}}$ & $70.40 \pm 0.01^{\mathrm{e}}$ \\
\hline
\end{tabular}

The values with the same alphabets are not significantly different from each other ( $\mathrm{p}<0.05)$; $\mathrm{A}=\mathrm{Jam}$ made without osmotic treatment $\left(60^{\circ} \mathrm{Brix}\right) \mathrm{B}=\mathrm{Jam}$ made from sample soaked in $50^{\circ} \mathrm{Brix}$ for $3 \mathrm{~h} ; \mathrm{C}=\mathrm{Jam}$ made from sample soaked in $50^{\circ}$ Brix for $4 \mathrm{~h} \mathrm{D}=\mathrm{Jam}$ made from sample soaked in $50^{\circ} \mathrm{Brix}$ for $5 \mathrm{~h}$

Table 2: Chemical composition of jam produced from prefrozen-cashew apple soaked in vary ing osmotic solution concentrations 3,4 and $5 \mathrm{~h}$

\begin{tabular}{|c|c|c|c|c|c|c|}
\hline Samples & TI (h) & TTA (\%) & $\mathrm{pH}$ & $\operatorname{Brix}\left({ }^{\circ}\right)$ & M.C (\%) & Vit C $(\mathrm{mg} / 100 \mathrm{~g})$ \\
\hline \multicolumn{7}{|l|}{$3 \mathrm{~h}$} \\
\hline A & 0 & $0.123 \pm 0.01^{\mathrm{a}}$ & $3.57 \pm 0.01^{c}$ & $58 \pm 0.00^{b}$ & $68.19 \pm 0.590^{\circ}$ & $105.260 \pm 0.00^{\mathrm{a}}$ \\
\hline B & 3 & $0.113 \pm 0.01^{\mathrm{a}}$ & $3.59 \pm 0.01^{\mathrm{c}}$ & $44 \pm 0.00^{\circ}$ & $78.23 \pm 1.320^{\mathrm{a}}$ & $82.720 \pm 0.01^{b}$ \\
\hline $\mathrm{E}$ & 3 & $0.110 \pm 0.01^{\mathrm{a}}$ & $3.63 \pm 0.01^{b}$ & $55 \pm 0.00^{c}$ & $74.90 \pm 0.390^{\circ}$ & $72.160 \pm 0.00^{d}$ \\
\hline $\mathrm{H}$ & 3 & $0.104 \pm 0.00^{b}$ & $3.67 \pm 0.01^{b}$ & $65 \pm 0.00^{\mathrm{a}}$ & $71.92 \pm 0.640^{\mathrm{d}}$ & $56.320 \pm 0.00^{g}$ \\
\hline \multicolumn{7}{|l|}{$4 \mathrm{~h}$} \\
\hline A & 0 & $0.123 \pm 0.01^{\mathrm{a}}$ & $3.57 \pm 0.01^{c}$ & $58 \pm 0.00^{b}$ & $68.19 \pm 0.590^{\circ}$ & $105.260 \pm 0.00^{a}$ \\
\hline $\mathrm{C}$ & 4 & $0.090 \pm 0.00^{b}$ & $3.71 \pm 0.01^{\mathrm{a}}$ & $48 \pm 0.00^{d}$ & $76.96 \pm 0.540^{b}$ & $75.680 \pm 0.01^{\mathrm{c}}$ \\
\hline $\mathrm{F}$ & 4 & $0.086 \pm 0.00^{c}$ & $3.63 \pm 0.01^{b}$ & $56 \pm 0.00^{b}$ & $74.49 \pm 0.360^{\circ}$ & $61.600 \pm 0.00^{f}$ \\
\hline I & 4 & $0.099 \pm 0.00^{b}$ & $3.71 \pm 0.01^{\mathrm{a}}$ & $68 \pm 0.00^{\mathrm{a}}$ & $70.41 \pm 0.350^{\circ}$ & $52.800 \pm 0.01^{\mathrm{h}}$ \\
\hline \multicolumn{7}{|l|}{$5 \mathrm{~h}$} \\
\hline A & 0 & $0.123 \pm 0.01^{\mathrm{a}}$ & $3.57 \pm 0.01^{c}$ & $58 \pm 0.00^{b}$ & $68.19 \pm 0.590^{\circ}$ & $105.260 \pm 0.00^{a}$ \\
\hline $\mathrm{D}$ & 5 & $0.089 \pm 0.00^{b}$ & $3.72 \pm 0.01^{\mathrm{a}}$ & $48 \pm 0.00^{d}$ & $75.55 \pm 0.350^{b}$ & $70.400 \pm 0.01^{\mathrm{e}}$ \\
\hline G & 5 & $0.071 \pm 0.00^{\mathrm{d}}$ & $3.75 \pm 0.01^{\mathrm{a}}$ & $58 \pm 0.00^{b}$ & $71.98 \pm 0.250^{d}$ & $52.800 \pm 0.00^{\mathrm{h}}$ \\
\hline$\underline{\mathrm{J}}$ & 5 & $0.070 \pm 0.00^{\mathrm{d}}$ & $3.76 \pm 0.01^{\mathrm{a}}$ & $67 \pm 0.00^{\mathrm{a}}$ & $69.90 \pm 0.650^{\circ}$ & $49.280 \pm 0.00^{\mathrm{h}}$ \\
\hline
\end{tabular}

The values with the same alphabets are not significantly different from each other $(\mathrm{p}<0.05)$; A = Jam made without osmotic treatment $\left(60^{\circ} \mathrm{Brix}\right) \mathrm{B}=\mathrm{Jam}$ made from sample soaked in $50^{\circ}$ Brix for $3 \mathrm{~h} ; \mathrm{E}=\mathrm{Jam}$ made from sample soaked in $60^{\circ}$ brix for $3 \mathrm{~h}, \mathrm{H}=\mathrm{Jam}$ made from sample soaked in $70^{\circ}$ brix for $3 \mathrm{~h} ; \mathrm{C}=\mathrm{Jam}$ made from sample soaked in $50^{\circ}$ Brix for $4 \mathrm{~h}, \mathrm{~F}=\mathrm{Jam}$ made from sample soaked in $60^{\circ}$ brix for $3 \mathrm{~h}, \mathrm{I}=\mathrm{Jam}$ made from sample soaked in $70^{\circ}$ brix for $3 \mathrm{~h}, \mathrm{D}=\mathrm{Jam}$ made from sample soaked in $50^{\circ}$ Brix for $5 \mathrm{~h}, \mathrm{G}=\mathrm{Jam}$ made from sample soaked in $60^{\circ}$ brix for $5 \mathrm{~h} \mathrm{~J}=$ Jam made from sample soaked in $70^{\circ}$ brix for $5 \mathrm{~h}$

Jam prepared from cashew apple soaked in $50^{\circ}$ brix for $3 \mathrm{~h}$ had the highest acidity of 0.113 while a value of 0.070 was recorded for jam produced from cashew apple soaked in $70^{\circ}$ Brix for $5 \mathrm{~h}$. Jam produced from untreated sample had TTA value of 0.123 with corresponding $\mathrm{pH}$ value of 3.57 .

This may be attributed to minimal leaching of organic acids into the osmotic solution. This result indicates that the higher the osmotic solution and the longer the soaking time, the lower the acidity in the samples. This observation is similar to that reported by Garcia-Martinez for kiwi jam and orange marmalade.

There was a progressive though significant increase in the brix levels of all the samples up to the 4 th $\mathrm{h}$ of soaking after which the brix remained constant. However, results in Table 2 showed that the brix level increased consistently with increase in osmotic solution concentration irrespective of soaking time. The brix level for all the jam samples ranged from $44-68^{\circ}$ with samples soaked in $50^{\circ}$ brix for $3 \mathrm{~h}$ having the least value and jam samples produced from cashew apple soaked in $70^{\circ}$ brix for $5 \mathrm{~h}$ had the highest value. Jam from untreated cashew apple had a brix value of $58^{\circ}$ brix.

This observation is consistent with the findings of Lazarides et al. (1999) in which short term osmosis under increased concentrations favoured solute uptake. However, from the definition of jam given by UNE that jam should have a final soluble solid of $45^{\circ}$ brix, it may be suggested that soaking cashew apple in $50^{\circ}$ brix for $3 \mathrm{~h}$ which yielded jam with brix level of $44^{\circ}$ brix may be appropriate for the process. The moisture content of the jam samples was observed to decrease significantly as the time of immersion increased. Similarly, the moisture content decreased significantly $(\mathrm{p} \leq 0.05)$ with increasing osmotic solution concentration (Table 2). This is not unexpected as osmotic dehydration has been reported to result in reduced water content depending on the process intensity (Shi and Maguer, 2002).

The vitamin $\mathrm{C}$ content of the various jam samples ranged from $49.3-82.7 \mathrm{mg} / 100 \mathrm{mg}$ with product obtained from $50^{\circ}$ brix, $3 \mathrm{~h}$ soaking having the highest value and those produced from $70^{\circ}$ brix, $5 \mathrm{~h}$ soaking had the least value. The untreated sample had a vitamin $C$ content of $105.3 \mathrm{mg} / 100 \mathrm{~g}$ (Table 2). This result reveals that there was a significant reduction in vitamin $\mathrm{C}$ contents of all the jam samples irrespective of the soaking time and osmotic solution concentration. This significant loss of vitamin C with increase in osmotic solution concentration may be due to other losses during processing which were not be accounted for.

However, as a panacea, vitamin $\mathrm{C}$ may be added to the osmotic solution to enhance the status of the vitamin in the jam product. This result contradicts previous findings of Lazarides et al. (1999) that as concentration increases sugar accumulates on the sample periphery from the osmotic solution which could block the escape of fruit 
Table 3: Mean sensory scores of texture, after taste and spreadability of the jam samples

\begin{tabular}{lccc}
\hline Samples & Texture & After taste & Spreadability \\
\hline A & $2.4^{\mathrm{a}}$ & $1.7^{\mathrm{d}}$ & $1.8^{\mathrm{b}}$ \\
$\mathrm{B}$ & $2.4^{\mathrm{a}}$ & $1.8^{\mathrm{d}}$ & $1.9^{\mathrm{b}}$ \\
$\mathrm{C}$ & $2.3^{\mathrm{a}}$ & $2.2^{\mathrm{c}}$ & $1.4^{\mathrm{c}}$ \\
$\mathrm{D}$ & $1.7^{\mathrm{c}}$ & $2.0^{\mathrm{c}}$ & $2.4^{\mathrm{a}}$ \\
$\mathrm{E}$ & $2.3^{\mathrm{a}}$ & $2.4^{\mathrm{b}}$ & $1.3^{\mathrm{c}}$ \\
$\mathrm{F}$ & $1.9^{\mathrm{b}}$ & $2.1^{\mathrm{c}}$ & $1.9^{\mathrm{b}}$ \\
$\mathrm{G}$ & $1.9^{\mathrm{b}}$ & $2.5^{\mathrm{b}}$ & $1.5^{\mathrm{c}}$ \\
$\mathrm{H}$ & $1.6^{\mathrm{c}}$ & $2.4^{\mathrm{b}}$ & $2.2^{\mathrm{a}}$ \\
$\mathrm{I}$ & $1.7^{\mathrm{d}}$ & $2.7^{\mathrm{a}}$ & $2.0^{\mathrm{b}}$ \\
$\mathrm{J}$ & $2.0^{\mathrm{b}}$ & $2.7^{\mathrm{a}}$ & $2.0^{\mathrm{b}}$ \\
\hline
\end{tabular}

The means with the same alphabets within a column are not significantly different from each other at $(\mathrm{p}<0.05)$

Table 4: Sensory properties of jams made from Osmo-dehydrated cashew \begin{tabular}{lcccc}
\multicolumn{2}{c}{ apple } & & & \\
Samples & Aroma & Colour & Taste & $\begin{array}{c}\text { Overall } \\
\text { acceptability }\end{array}$ \\
A & $6.5^{\mathrm{c}}$ & $6.1^{\mathrm{d}}$ & $7.0^{\mathrm{b}}$ & $6.7^{\mathrm{c}}$ \\
$\mathrm{B}$ & $6.3^{\mathrm{e}}$ & $6.4^{\mathrm{c}}$ & $6.5^{\mathrm{g}}$ & $6.1^{\mathrm{g}}$ \\
$\mathrm{C}$ & $6.3^{\mathrm{e}}$ & $7.0^{\mathrm{b}}$ & $6.7^{\mathrm{e}}$ & $6.2^{\mathrm{f}}$ \\
$\mathrm{D}$ & $6.7^{\mathrm{b}}$ & $7.2^{\mathrm{a}}$ & $7.2^{\mathrm{a}}$ & $7.1^{\mathrm{a}}$ \\
$\mathrm{E}$ & $7.1^{\mathrm{a}}$ & $7.3^{\mathrm{a}}$ & $6.9^{\mathrm{a}}$ & $6.9^{\mathrm{b}}$ \\
$\mathrm{F}$ & $6.7^{\mathrm{b}}$ & $6.9^{\mathrm{b}}$ & $6.8^{\mathrm{d}}$ & $7.1^{\mathrm{a}}$ \\
$\mathrm{G}$ & $7.1^{\mathrm{a}}$ & $6.1^{\mathrm{d}}$ & $6.5^{\mathrm{g}}$ & $6.6^{\mathrm{d}}$ \\
$\mathrm{H}$ & $6.3^{\mathrm{e}}$ & $6.0^{\mathrm{d}}$ & $5.9^{\mathrm{i}}$ & $6.0^{\mathrm{h}}$ \\
$\mathrm{I}$ & $6.3^{\mathrm{e}}$ & $6.3^{\mathrm{c}}$ & $6.0^{\mathrm{h}}$ & $6.0^{\mathrm{h}}$ \\
$\mathrm{J}$ & $6.4^{\mathrm{d}}$ & $7.2^{\mathrm{a}}$ & $6.6^{\mathrm{f}}$ & $6.4^{\mathrm{e}}$ \\
\hline
\end{tabular}

The mean with the same alphabets within a column are not significantly different from each other at $(\mathrm{p}<0.05)$

solubles contained in the fruit. Data on the sensory evaluation of the jams including the descriptive test are shown in Table 3 and 4 . The result revealed that both osmotic solution concentration and soaking time had significant influence on all the sensory attributes measured, the extent of which depends on the intensity of the process. Untreated sample, jam products produced from cashew apple soaked in $50^{\circ}$ brix for $3,4 \mathrm{~h}$ and $60^{\circ}$ brix for $3 \mathrm{~h}$ had similar scores which were the best in terms of texture. In terms of after taste the untreated sample and jam prepared from cashew apple soaked in $50^{\circ}$ brix for $3 \mathrm{~h}$ had the best ratings while for spreadability, jam produced from cashew apple soaked in $50^{\circ}$ brix for $5 \mathrm{~h}$ was the most favoured among other samples. The panelists adjudged jam product from cashew apple soaked in $60^{\circ}$ brix for $3 \mathrm{~h}$ the best in terms of aroma and colour while jam from cashew apple soaked in $50^{\circ}$ brix for $5 \mathrm{~h}$ was better favoured in terms of taste and overall acceptability among other samples. This observation may be attributed to the various mass exchanges during osmotic dehydration process.

\section{CONCLUSION}

This study showed that an acceptable jam product could be produced from osmo-dehydrated cashew apple. The result of chemical composition of jam produced from cashew apple soaked in different osmotic solution concentration and immersion time suggests that soaking in $50^{\circ}$ brix for $3 \mathrm{~h}$ may be appropriate to produce an acceptable jam product. The result from this research has demonstrated the potentials of cashew apple in jam making and has provided useful product development outlets for osmotic solutions which until now have remained grossly underutilized in Nigeria and other countries. This will not only reduce post-harvest losses which have been a challenge to Nigerian Food technologists but it would also help create job opportunities and contribute to the development of Nigerian agro-allied economy.

\section{REFERENCES}

AOAC., 1990. Official Methods of Analysis. 15th Edn., AOAC Press, Gaithersburg, USA.

Ade-Omowaye, B.I.O., G.O. Ogunlakin, A.O. Abioye and M.O. Oke, 2007. Review of osmotic dehydration of fruits and vegetables from the perspective of its potential application in food processing in Nigeria. Lautech J. Eng. Technol., 4: 28-33.

Aderiye, B.I., M.A. Akpapunam and P. Akubor, 1991. Effect of fermentation variables on the quality of cashew wine. J. Agric. Sci. Technol., 1: 66-69.

Akinwale, T.O., 1999. Fermentation and post fermentation changes in cashew wine. J. Food Technol. Afr., 4: 100-102.

Akinwale, T.O., 2000. Cashew apple juice: Its uses in fortifying the nutritional quality of some tropical fruits. Eur. Food Res. Technol., 211: 205-207.

Cavalcante, A.A.M., G. Rubensam, B. Erdtmann, M. Brendel and J.A.P. Henriques, 2005. Cashew (Anacardium occidentale) apple juice lowers mutagenicity of aflatoxin Bl in S. typhimurium TA102. Genet. Mol. Biol., 28: 328-333.

Cormier, R., 2008. Clarification of Cashew Apple Juice and Commercial Applications. Oxfarm Quebec, Benin, West Africa.

Garcia-Martinez, E., G. Ruiz-Diaz, J. Martinez-Monzo, M.M. Camacho, N. Martinez-Navarrete and A. Chiralt, 2002. Jam manufature in osmo-dehydrated kiwi fruit characterization of reused osmotic solution as ingredient in new product formulation. Food Resour. Int. J., 35: 307-313.

Gomez, A.K. and A.A. Gomez, 1985. Statistical Procedure for Agricultural Research. Wiley, New York.

Lazarides, H.N., P. Fito, A. Chiralt, V. Gekas and A. Lenart, 1999. Advances in Osmotic Dehydration. In: Processing Foods, Quality Optimization and Process Assessments, Oliveira, A.R.F. and J.C. Oliveira, CRC Press, London, pp: 175-199. 
Melo-Cavalcante, A.A., G. Rubensam, J.N. Picada, E.G. Silva, F.J.C. Moreira and J.A.P. Henriques, 2003. Mutagenic evaluation, antioxidant potential and antimutagenic activity against hydrogen peroxide of cashew (Anacardium occidentale) apple juice and cajuina. Environ. Mol. Mutagen., 41: 360-369.

Morton, J., 1987. Cashew Apple. In: Fruits of Warm Climates, Miami, F.L. (Ed.). E.C.H.O. Inc., Myers, FL., pp: $239-240$.

Oduwole, O.O., T.O. Akinwale and O. Olubamiwa, 2001. Economic evaluation of a locally fabricated extraction machine for a cottage cashew juice factory. J. Food Technol. Afr., 6: 18-20.

Ogunmoyela, A.O., 1983. Prospects of cashew apple processing and utilization in Nigeria. Process. Biochem., 23: 6-7.

Ohler, J.G., 1988. Cashew Communication 71. Koninklijk Institnut voor de Tropen, Amsterdam, ISBN: 9068320742, pp: 260.
Shi, J. and M.L. Maguer, 2002. Osmotic dehydration of foods mass transfer and modeling aspects. Food Rev. Int., 18: 305-335.

Shuklajasha, M., P. Ray, M.R. Swain and R.C. Ray, 2006. Fermentation of cashew (Anacardium occidentale) apple into wine. J. Food Process. Preservation, 30: $314-322$.

Steel, R.G.D. and J.H. Torrie, 1980. Principles of Statistics. A Biometric Approach. McGraw-Hill Publications, New York, pp: 633.

Taiwo, K.A., C.T. Akanbi and O.O. Ajibola, 1997. Establishing processing conditions for canning cowpea seeds in tomato sauce. Int. J. Food Sci. Technol., 32: 313-324.

Winterhalter, P., 1991. Fruits IV. In: Volatile Compounds in Foods and Beverages, Mearse, H. (Ed.) Marcel Dekker, New York, ISBN: 9780824783907, pp: 389-409. 